\title{
Sosyal Medyada Çocuk Hakları îhlalleri: Ebeveynler ve Öğretmenler Farkında mı?
}

\author{
Hüseyin SERIN*
}

Sosyal Medyada Çocuk Hakları Ihlalleri: Ebeveyn-
ler ve Öğretmenler Farkında mı?

Özet

Bilgi iletişim teknolojilerinin etkileri her geçen gün artmaktadır. Bilgi iletişim teknolojilerinde yaşanan değişim ve gelişmeler kişiler arası iletişimi, etkileşimi, sosyal ve kültürel yaşamı yeniden yapılandırmaktadır. Bu gelişim ile beraber ortaya çıkan sosyal ağlar, insanların birbiriyle olan iletişiminde kolaylıklar sağlarken, bazı problemlerin ve etik ihlallerinin de ortaya çıkmasına neden olmaktadır. Dijital araçların kullanımının yaygınlaşmasıyla beraber kişilere ait bilgilere erişim daha da kolaylaşmış, kişilerin özel verilerinin hukuka aykırı biçimde kötü niyetli kişilerin eline geçmesine neden olmuş, böylece kişilerin özel yaşamlarına ilişkin şahsi verilerinin hukuka aykırı bir şekilde ifşa edilme korkusu ortaya çıkmıştır. Bu çalışmada sosyal medya kullanımı ile çocuk hakları konusu uluslararası ve ulusal mevzuat çerçevesinde tartışılmıştır. Özellikle sosyal medya aracılığıyla çocuk istismarını önlenmesi, kişilik haklarının korunması için ebeveynlere, okullara ve öğretmenlere önerilerde bulunulmuştur.

Anahtar Kelimeler: Sosyal Medya Kullanımı, Çocuk İstismarı, Çocuk Hakları, Çocuğun Kişilik Hakları

\author{
Violation of Children's Rights Through Social \\ Media: Are the Parents and Teachers Aware of It ? \\ Abstract
}

The impacts of information technologies are growing day by day. The changes and developments in information technologies are reconstructing interpersonal communication, interaction, social and cultural lives of people. While social networks that have emerged with such developments, provide ease in interpersonal communication; they also cause certain problems such as legal and ethical violations. With the spread use of digital devices, it is now easier to access to personal data and this has caused such data to be illegally used by malicious individuals and thus has raised concerns about the unlawful disclosure of personal data, regarding their private lives. In this study, the use of social media and the matter of children's rights are discussed within the framework of international and national legislations. Specifically, recommendations to parents and teachers are made about the prevention of child abuse throughsocial media andprotection of human rights.

Key Words: Social Media Use, Child Abuse,Children's Rights, Child's Personal Rights

\section{Giriş}

Bilgi iletişim teknolojilerinin varlığı, hızı, genel yaşama etkileri her geçen gün artmaktadır. Bilgi iletişim teknolojileri alanında yaşanan gelişmeler ve hızlı değişimler kişiler arası iletişimi, sosyal ve kültürel yaşamı yeniden şekillendirmektedir. Bu gelişmelerle ile beraber ortaya çıkan sosyal ağlar, insanların birbiriyle olan iletişiminde kolaylıklar sağlarken, bazı problemlerin ve hukuki ihlallerin de ortaya çıkmasına neden olmaktadır.

\footnotetext{
* Hüseyin SERIN, Dr.Öğr.Üyesi., İstanbul Üniversitesi, Cerrahpaşa Hasan Ali Yücel Eğitim Fakültesi, Eğitim Bilimleri Bölümü, huseyin.serin@istanbul.edu.tr, ORCID ID orcid.org / 0000-0003-3002-8787
} 
Hüseyin SERIN

Bilgi iletişim teknolojilerinin yoğun kullanımıyla beraber sosyal medya platformları ortaya çıkmış, bu platformlarda içerik paylaşımı kolaylaşmış ve bu içerikler hızlı ve rahat paylaşılır hale gelmiştir. Bu süreçte sosyal medya platformlarını kullananlar birer içerik üreticisi haline gelmiş, kullanıcıların yoğun etkileşimi bu araçları çok yönlü hale getirilmiş; sosyal medya platformlarının hızlı değişim ve gelişimi avantajlar sağlamasının yanında bazı önemli risklerinde ortaya çıkmasına zemin hazırlamıştır.

Son dönemlerde bilgi iletişim teknolojileri alanında yaşanan gelişmeler ve internetin yaygın kullanımıyla beraber kişilerle ilgili bilgilerin sanal ortamlarda artması ve internet yoluyla kişisel bilgilere erişimin kolaylaşması kişisel özel bilgi ve verilerin hukuka aykırılık teşkil edebilecek bir şekilde yetkisiz ve genellikle art niyetli kişilerin eline geçmesine neden olmuş, böylelikle bireylerin özel yaşamlarına ilişkin kişisel verilerinin hukuk kurallarına aykırı bir şekilde alenileşmesi kaygısı ortaya çıkmıştır (Sırabaşı, 2007).

Çocukların sosyal medya platformlarında bulunabilecekleri gerçeği yetişkin bireyler tarafından ihmal edilebilmekte, çocukların psiko-sosyal, bilişsel, cinsel ve bedensel gelişimlerini olumsuz yönde etkileyebilecek aynı zamanda toplumun genel ahlak kurallarıyla bağdaşmayacak paylaşımların sosyal medya araçları üzerinden yapılması önemli hukuki, ahlaki ve etik ihlallerin ortaya çıkmasına neden olabilmektedir.

Birleşmiş Milletler Uluslararası Çocuklara Yardım Fonu (UNICEF) 2018 yılında yayımlamış olduğu bildiride tüm dünyada her gün 175 binden fazla çocuğun internet ortamına katılım sağladığını, dijital erişimin çocuklara bir takım yararlar ve fırsatlar sunduğunu belirtmiştir. Bununla beraber cinsel istismar, siber zorbalık, zararlı içeriğe ulaşma ve çocuk yaştaki bireylere ait özel bilgilerin kötüye kullanımı gibi bir dizi risklere kapı araladığı belirtilmiştir (Unicef, 2018).

Dijitalleşmeyle beraber sosyal medya kullanımı Türkiye'de de hızı bir şekilde artış göstermiştir. We Are Social (2019)'un Ocak ayı verilerine göre Türkiye de 52 milyon sosyal medya kullanıcısı bulunmaktadır. Sosyal medya kullanıcılarının \% 55'i youtube, \% 53'ü facebook, \% 50'si whatsapp, \% 46'sı instagram ve \% 36'sı twitter gibi sosyal medya araçlarını aktif bir şekilde kullanmaktadır. Yaygın kullanılan sosyal medya platformlarından biri olan Facebook'un dünya geneli kullanım oranında Türkiye Avrupa' da ilk, dünyada dokuzuncu sıradadır. Facebook'un 2019 istatistiklerine göre Türkiye'de 18 yaş üstü kullanıcı sayısının 43 milyon civarında olduğu görülmektedir. Yine aynı şekilde We Are Social tarafından 2018 yılı ilk çeyreği için yayınlanan Western Asia verilerine göre Türkiye'de nüfusun yaklaşık \% 60' ı her gün ortalama 3 saat 1 dakika sosyal medya kullanmaktadır (Statista, 2018; Wearesocial, 2018; Wearesocial, 2019). 
Sosyal medyada sürdürülen etkileşimlerde paylaşılan fotoğraflar ya da videoların önemli bir yer tuttuğu görülmektedir. İngiltere'de yapılan bir araştırmaya göre, sosyal medya araçlarını kullanan ebeveynler çocuklarının beşinci yaş gününe kadar ortalama 1.498 fotoğraf-videolarını paylaşmış olmaktadır (BBC, 2018). Son dönemlerin popüler sosyal medya uygulamalarından biri olan Instagram'da 1 milyardan fazla aylık aktif kullanıcı tarafından, günlük yaklaşık 95 milyon fotoğraf paylaşılmaktadır. Instagram’ın dünya geneli kullanımında Türkiye 5. sırada yer almaktadır (Statista, 2018; Webional, 2018).

Dijital dünyada paylaşımların hızlı bir şekilde artmasıyla beraber ebeveynlerin ve öğretmenlerin sorumluluklarının da yeniden gündeme gelmesi zorunlu görülmektedir. Türk Medeni Kanunu'nun 339. maddesine göre; "Ana ve baba, çocuğun bakım ve eğitimi konusunda onun menfaatini göz önünde tutarak gerekli kararları alır ve uygularlar. " denilmektedir. Ebeveynler, kanunun vermiş olduğu bu hakkı çocuğun yüksek menfaatini gözeterek kullanmak zorundadırlar. Anne ve baba çocuğun haklarını korumakla yükümlüdür. Velâyet hakkı ilgili maddede de görüldüğü üzere, sınırsız değildir. Sosyal ağlarda yetişkinlerin, kendi fotoğraf ve videolarını belirli sınırlar çerçevesinde paylaşmasında bir sakınca bulunmamaktadır. Fakat kendi adına karar veremeyen çocuklarla ilgili paylaşımlarda bulunmak, bir nevi onların kullanmaya haiz olamadıkları haklarını istismara girmektedir. Sosyal paylaşım siteleri üzerinden izinsiz fotoğraf ve görüntü paylaşımı, karşılaşılan en önemli problemlerden biridir. Paylaşımların, ebeveyn veya okul ortamında uzun süre beraber zaman geçirdikleri öğretmenleri tarafından yapılmış olması, çocuk hukuku bağlamında çocukların korunması gereken haklarının ihlal edildiği gerçeğini değiştirmemektedir.

Özellikle sosyal medya araçları üzerinden daha fazla popüler olmak amacıyla öğretmenler tarafından eğitim ortamlarında çocuklarla ilgili yapılan paylaşımlarda artışların meydana geldiği gözlenmektedir. Sosyal medya üzerinden yapılan bu paylaşımlar, kısa süre içerisinde milyonlarca kişiye ulaşabilmekte bu durum çocukları duygusal anlamda etkileyebilmektedir. Her türlü teşhir, izinsiz paylaşım ve istismar; çocukların psiko-sosyal gelişimlerine olumsuz etkilere neden olabileceğinden uluslararası ve ulusal mevzuatta bu tür fiiller yasaklanmıştır. Türkiye'de Milli Eğitim Bakanlığı tarafından eğitim kurumlarında bu tür durumların önüne geçmek amacıyla öğretmenlerin eğitim ortamlarında elde etmiş oldukları görüntü ve fotoğraf paylaşımlarında dikkat etmeleri gereken hususları açıklayan bir genelge yayınlanmıştır.

İnternet ve sosyal medya kullanımının artması, pedofili davranışlarının artması için bir risk oluşturmaktadır. Pedofili "çocuk istismarcısı" olarak tarif edilebilir. Resim ve video gibi görsel imajlar üzerinden de istismar gerçekleşebilmektedir. Sosyal medya araçları, pedofiller için de çocukları rahat istismar edebilecekleri bir ortam sağlayabilmektedir. Dijital araçlar ve sosyal medya platformları üzerinden cinsel istismara uğrayan çocuklar da gerçek yaşamda cinsel istismara uğrayan çocuklarla benzer bulguları, aynı semptomları 
Hüseyin SERIN

gösterebilmektedir. Bunun yanında intihar girişiminden, depresyona; psikomatik eğilimlerden, post travmatik stres bozukluğuna kadar pek çok farklı rahatsızlık söz konusu olabilmektedir (Alikaşifoğlu, 2012).

Çocuğun korunması, onun "bir birey" olarak sevgi, saygı, ilgi ve şefkate layık olmasının yanı sıra toplumun da önemli bir öğesi olması fikrine dayanır. Bir toplumda çocuklar insanlık onuruna yakışmayacak şekilde kötü muameleye tabi tutuluyorsa, ihmal ve istismar ediliyorsa, o toplumun kültürel anlamda geri kaldığı ifade edilebilir. Buna karşın, çocuklarına sağlıklı, psiko-sosyal gelişme olanakları ve ortamları sağlayan, değer veren toplumların ileri bir kültür düzeyinde oldukları söylenebilir (İnan, 1968; Roma, 1966; akt. Akyüz, 2016). Çocuk haklarının önemsenmediği bir toplumda, yetişkinler de insan haklarından nasiplerini alamayacaklardır (Serozan, 2017).

\section{Sosyal Medya}

Dünya coğrafyasının tümünde olmasa bile, çok önemli bir kısmında internet erişiminin mevcut olması nedeniyle de hızlı bir yaygınlığa erişen toplumsal paylaşım ağları; 21. yüzyılın ilk on yılında ortaya çıkan siyasal, toplumsal, kültürel ve ekonomik gelişmeleri elektronik küreselleşme bağlamında ele almak gereğini doğurmuş; sosyal bilimler alanında yapılan çalışmaların da içerik ve yaklaşımlarını etkilemeye, yönlendirmeye başlamıştır (Bostancı, 2010).

Sosyal ağlar; web sayfaları üzerinde rahat düzenlemeler yapılmasına izin veren wikiler, forumlar, bloglar, mikrobloglar, otomatik olarak internet üzerinden indirilebilen, dijital formatta yer alan müzik veya konuşmaları içeren podcastler ve sanal oyun ortamları ile içerik toplulukları gibi farklı tür veya ortamlara sahip olan sosyal medya platformları, kullanıcıların kendileri ile ilgili kişisel bilgi ve haberleri duyurabilecekleri, yeni arkadaşlar edinebilecekleri, arkadaşları veya diğer başka kişilerle karşılıklı iletişim kurabilecekleri, yazılarını, videolarını, fotoğraflarını paylaşabilecekleri, çeşitli etkinlikler gerçekleştirebilecekleri web sitelerine genel olarak verilen addır (Eldeniz, 2010).

Sosyal medya; çevrimiçi olarak, web siteleri, forumlar, sohbet odaları, bloglar, elektronik posta, müzik paylaşım siteleri, iş ağ siteleri, sözlükler, internet tartışma platformları, video - resim paylaşım siteleri, sosyal ağları ve podcastleri kapsamaktadır (Mangold ve Faulds, 2009). Sosyal medya, kullanıcılarının açık veya kısmen kapalı profil oluşturup, etkileşim kurmak istediklerinin listesini hazırlayabildikleri, bunları sergiledikleri, paylaştıkları ve başka kullanıcıların profillerini, bilgi, paylaşım ve etkileşimlerini izleyebildikleri sanal bir ortamdır (Boyd ve Ellision, 2008). 
Sosyal medya platformlarını önemli kılan şey, paylaşımın bu mecralarda kolay olmasıdır. Kullanıcılar, sosyal medya araçlarında karşılaştıkları herhangi bir içeriği, paylaşım yoluyla diğer kişilere daha hızlı ve kolay bir şekilde aktarabilmekte, beğenme ve yorum yapma gibi özellikler sayesinde de içeriklere rahat bir şekilde geri bildirimde bulunabilmektedir (Zengin, Zengin ve Altunbaş, 2015).

Sosyal medya platformlarının temel özellikleri şu şekilde sıralanabilir (Mavnacıoğlu, 2009);

- Mekân ve zaman sınırlaması olmayan, paylaşımın esas olduğu bir internet uygulamaları zinciridir.

- Kişiler, kendi oluşturdukları içerikleri çok rahat bir şekilde internet ortamında ve bilgi iletişim araçlarında yayımlamaktadır.

- Kişiler, diğer kullanıcıların paylaşımlarını, paylaşımların içeriklerini ve yorumlarını takip etmektedirler.

- Kişi, sosyal medya platformlarında hem takipçi hem de takip edilen olabilendir.

- Sınırları, kuralları, önceden tanımlanmış bir etkileşime değil samimi bir sohbet mantığına dayanır.

- İçeriklere bakıldığında; informal oldukları, belirli bir zaman sonra etkileşim halinde olanlar arasında dedikodu zincirine dönüşebildikleri görülmektedir.

Sosyal medya; televizyon, radyo, gazete ve sinema gibi geleneksel medya araçlarından ciddi anlamda farklıklar göstermektedir. Geleneksel medya araçları bilginin yayınlanması için bazı kaynaklara ihtiyaç duyarken, sosyal medya araçları ise bilgiyi yayınlamak veya bilgiye erişim sağlamak için göreceli olarak daha masrafsızdır ve erişim araçları herkese açık olabilmektedir. Sosyal medyada yayın yapabilmek için geleneksel medya araçlarında olduğu gibi lisansa ihtiyaç duyulmamaktadır (Bostancı, 2010). Bu durum sosyal medya araçlarının kullanımının artmasına ve aynı zamanda sosyal medya kullanımında kontrolsüzlüğe yol açmaktadır.

Sosyal medya kullanıcıları, yalnızca yakın çevrelerinden oluştuğunu düşündükleri arkadaşları kendilerini izlerken, yaşamlarını elektronik ortamda arşivlemektedirler. Ancak kişisel bilgi ve paylaşımlarının yalnızca kendi onayladıkları kişiler tarafından mı; yoksa kendileri ile ilgili bilgi toplama amacındaki şirketler veya yönetimler tarafından mı izlendiği konusunda yeterli bir farkındalığa sahip değildirler. Bu anlamda kullanıcının kamu ile paylaştığı ve sosyal medyanın derinliklerinde kaybolduğunu düşündüğü her türlü kişisel bilgi, bilgiyi güç olarak gören otoritelerin kullanımına sunulmakta, beklenmedik bir anda aleyhte kullanılabilecek şekilde arşivlenip depolanmakta, dolayısıyla kullanıcı eski bir hükümlü gibi sosyal ağlardaki sanal izlerini hayatı boyunca taşımaktadır (Kızılarslan, 2012). 
Hüseyin SERIN

Yeni nesil medya araçlarıyla birlikte dengeler yerinden oynamaktadır. İletişim kuralları, okuma yazma stilleri değişime uğramakta ve bireyler tarafından yeni yeni iletişim dilleri türetilmektedir. Köklü değişikliklere neden olan yeni nesil medya araçları, iletişim süreçlerinden, bireylerin yaşam tarzlarına ve daha birçok dinamiklerini değiştirmeye devam etmektedir (Yengin, 2012).

Sosyal medya kullanımının artması; çocuk istismarı, siber zorbalık, güvenlik, kişilik hakları kavramlarını da önemli hale getirmektedir. Bu kavramların sosyal medya kullanımı bağlamında yeniden değerlendirilmesi, sosyal medya araçları üzerinden yapılan paylaşımların etki alanı hakkında daha fazla düşünülmesine yardımcı olacaktır.

\section{3. Çocuk İstismarı}

Dünya Sağlık Örgütü (World Health Oranization-WHO) tarafından, çocuğun sağlığını, fiziksel ve psiko-sosyal gelişimini olumsuz şekilde etkileyen yetişkin bir birey, toplum veya devlet tarafından bilinçli veya bilinçsiz yapılan davranışlar biçiminde tanımlanan çocuk istismarı, başka bir ifade ile çocukların ebeveynleri ya da diğer başka bireyler tarafından beden ve ruh sağlığını olumsuz etkileyen, duygusal, zihinsel, bedensel gelişimlerini engelleyen, kaza sonucu gerçekleşmeyen durumlar olarak ifade edilebilmektedir (WHO, 2006; Nasıroğlu, 2014).Çocuk istismarı kavramı; çocukların ebeveynleri gibi, onlara bakıp korumakla görevli, sorumluluk, güç ve güven ilişkisi içinde oldukları kişiler ya da tanımadıkları kişiler tarafından psikolojik veya beden sağlığına zarar verecek, psiko-sosyal gelişimlerini engelleyecek biçimde uygulanan tüm duygusal, fiziksel ya da cinsel yaklaşımları, ticari amaçla sömürüyü, ihmali kapsar (Şahin, 2006; akt. Taş, 2017).

Toplumun önemli bir öğesi olan çocuğun yetişmesi bedensel, duygusal, zihinsel ve ahlakî gelişimi ile ilgili eğitsel tedbirlerin alınmasının yanında, onun toplum ve aile içindeki yerini düzenleyen hukuk kurallarına da bağlıdır. Çünkü ihtiyaçları yeterli düzeyde karşılanmamış, temel haklarından yoksun bırakılmış, üzerinde doğal güçsüzlüğü nedeniyle ebeveynin, okul yöneticisinin, öğretmenin, bakıcısının, işverenin, polisin, hâkimin ve savcının her türlü baskıda bulunabileceği bir obje olarak algılanan çocuğun, hukuk kurallarıyla korunması gerekir. Bu kuralların çocuğun saygınlığı, onuru, şeref ve haysiyeti, özgürlüklerine uygun olmasında, çocuğun olduğu kadar toplumun da yararı vardır. İşte bu nedenlerden dolayı, toplumun önemli unsuru olan çocuk eski devirlerden bu yana hukuk alanını ilgilendirmiştir (İnan, 1968; akt. Akyüz, 2016).

Çocuk, bedensel ve psiko-sosyal gelişimini tamamlamamış olmasından dolayı kendine has özel politikalara ihtiyaç duyar. Çocukların gelişimlerini tamamlamamış olmaları onları bir risk grubu haline getirmektedir. Çeşitli istismar durumlarına karşı kendini koru- 
ma ve kollama olanağından yoksun bulunan çocukların öncelikle zihin ve beden bütünlügünün korunması bu bakımdan içinde yaşanılan toplumla birlikte devletin de önemli görevi olarak kabul edilmektedir. Çocuk refahının önündeki engeller genellikle çocuğun mensubu bulunduğu aile ve toplum tarafından şekillendirilirken, çocukken yaşanan problemler ilerleyen zamanlarda toplumun ve o çocuğun kurmuş olacağı ailenin sorunlar yaşamasına neden olabilme potansiyeline sahiptir. Bu bakımdan çocukların yaşadığı problemler sadece o çocuğu ya da mensubu bulunduğu aileyi ilgilendirmenin ötesinde bütün toplumun sorunudur. Çocuk hakları bu bakımdan tüm çocukları kapsayacak bir biçimde korunması ve geliştirilmesi gereken haklardır (Karakaş ve Çevik, 2016).

Çocuğun saygınlığı ve onuru; onu küçük düşürebilecek eylemlerle, karalayıcı, aşağılayıcı ve horlayıcı görüntü, ses ve resimlerinin başkaları tarafından kullanılıp, paylaşılması ve istismar edilmesiyle ihlal edilebilir. Onur ve saygınlığının bu hareketlerle çiğnenmesi, çocuğun özel yaşamının gizliliğinin ayaklar altına alınmasına sebep olabilir (Serozan, 2017). Sosyal medya üzerinden kolay bir şekilde yapılabilen paylaşımlar çocuk istismarının artmasına ve daha kolay bir şekilde gerçekleşmesine neden olabilir. Bu sonuç çocuk haklarının daha fazla ihmal edilebileceğini göstermektedir.

\section{4. Çocuk Hakları}

Çocuk hukukunun başlıca konusu; çocuk haklarıdır. Çocuk hukukunun, çocuk hakları ile özdeşleştirilmesi de bundandır. Çocuklarla ilgili gelişmelerin en yoğun yaşandığı dönem 20. yüzyıldır. Ancak bu dönemdeki çalışmaların kökenleri oldukça eskiye dayanmaktadır. İspanyol filozof Vites, 15. yüzyılın sonlarında çocukların korunup kollanmasına ilişkin bazı ilkelerden söz etmiştir. Bunlar hukuksal ilkelerden çok, eğitim ilkeleri niteliğindedir. İsviçreli eğitimci Pestalozzi, 18. yüzyılın sonlarında yoksul çocukların eğitimsizlikleri ve sefaleti sorununa değinmiş; çocukların aile içinde ebeveynleri tarafından, anne ve babası olmayan çocukların da koruyucu aileler tarafından eğitilmelerinin önemi üzerinde durmuştur. Çocukluğun toplumsal, eğitsel ve hukuksal kurumlar çerçevesinde korunan bir kavram halini alarak, çocuk hakları ve çocuğun korunması düşüncesi 20. Yüzyılda gelişim göstermiştir. Çocuk hakları konusunda birçok belge düzenlenmiş, bu konuda büyük ilerleme kaydedilmiştir. Çocuk hakları konusunda düzenlenen en önemli belge Birleşmiş Milletler Çocuk Haklarına Dair Sözleşmedir.. Birleşmiş Milletler Çocuk Haklarına Dair Sözleşme, çocuk haklarını kapsamlı bir şekilde düzenleyerek bağımsız bir çocuk hukukunun temelini atmıştır. Birleşmiş Milletler Çocuk Haklarına Dair Sözleşme ve diğer uluslararası hukuk metinlerinde çocuklarla ilgili önemle vurgulanan husus, çocuğun kişiliğinin tanınması ve cezalandırmadan çok önleyici ve iyileştirici olan çocuklara özgü bir yargılama sistemi ve çocuğun yararının gözetildiği bağımsız bir çocuk hukukunun oluşturulmasıdır (Akyüz, 2000; Çobaner, 2015; Serozan, 2017). 
Hüseyin SERIN

\subsection{Uluslararası Sözleşmelerde Çocuk Hakları}

Uluslararası hukukun önemli kaynaklarını milletlerarası sözleşmeler oluşturmaktadır. Milletlerarası sözleşmeler, "ahde vefa (pacta sunt servanda)" ilkesi gereği andlaşmaya taraf devletleri bağlar. Bu sözleşmeler, aynı zamanda iç hukuk bakımından da bağlayıcılığı olan işlemlerdir (Gözler, 2001).

Türkiye Cumhuriyeti Anayasasının 90. maddesine göre, "usulüne göre yürürlüğe konulmuş milletlerarası andlaşmalar kanun hükmündedir. Usulüne göre yürürlüğe konulmuş temel hak ve özgürlüklere ilişkin milletlerarası antlaşmalarla kanunların aynı konuda farklı hükümler içermesi nedeniyle çıkabilecek uyuşmazlıklarda milletlerarası andlaşma hükümleri esas alınır" denilmektedir.

Çocuk haklarının korunmasıyla ilgili Türkiye'nin de taraf olduğu önemli bazı uluslararası andlaşmalar bulunmaktadır.

\subsubsection{Birleşmiş Milletler Çocuk Haklarına Dair Sözleşmede Çocuk Hakları}

Birleşmiş Milletler Çocuk Haklarına Dair Sözleşme 1989 tarihinde kabul edilmiş ve 2 Eylül 1990 tarihinde yürürlüğe girmiştir. Birleşmiş Milletler Çocuk Haklarına Dair Sözleşme'nin başlangıç kısmında belirtildiği üzere bu metin; Uluslararası İnsan Hakları Evrensel Bildirisinde Birleşmiş Milletlerin, çocukların özel ilgi ve yardım hakkı olduğunu ilan etmesi göz önünde bulundurularak, toplumun temel birimi olan ve bütün fertlerinin ve özellikle çocukların gelişmeleri ve esenlikleri için doğal ortam oluşturan ailenin, toplum içinde gereken sorumlulukları icra edebilmesi için gerekli koruma ve yardımı görmesi zorunluluğu dikkate alınarak taraf devletlerce hazırlanmıştır (Balo, 2005).

Sözleşme Türkiye'de Bakanlar Kurulu tarafından 09.12.1995 tarihinde onaylanmış, 27.01.1995 tarihli Resmi Gazete 'de yayımlanarak yürürlüğe girmiştir. Türkiye Cumhuriyeti sözleşmenin 19, 29 ve 30. maddelerine T.C. Anayasası ve Lozan Anlaşması hükümlerine ve ruhuna uygun olarak yorumlama hakkını saklı tutarak çekincelerini ortaya koymuştur.

Birleşmiş Milletler Çocuk Hakları Sözleşmesi'nde; “Bu yasaya taraf ülkelerin, çocuğun ana- babasının ya da onlardan yalnızca birinin, yasal vasi veya vasilerinin bakımını üstlenen herhangi bir kişinin yanında bedensel veya zihinsel saldırı, şiddet ve ya suistimale, ihmal ya da ihmalkâr muameleye, ırza geçme dâhil her türlü kötü muamele ve istismara karşı korunması için, yasal, toplumsal, idari, eğitsel bütün önlemleri almaları gerekmektedir." ifadesi yer almakta ve çocuk istismarları sözleşmede yer alan devletlerde önlenmeye çalışılmaktadır (Pelendecioğlu ve Bulut, 2009). 
Çocuk istismarı, çocuk hakları açısından yaşamsal gelişme ve koruma hakları kapsamında düşünülmektedir. Birleşmiş Milletler Çocuk Hakları Sözleşmesinde; yaşamsal haklar, çocuğun yaşama, barınma, beslenme ve tıbbi bakım gibi en temel ihtiyaçlarının karşılamasını içermektedir. Gelişme hakları ise çocuğun fikir özgürlüğü, eğitim, oyun ve dinlenme haklarını içermektedir. Çocuk hakları sözleşmesinde yer alan koruma hakları ise doğrudan istismarla ilgilidir. Bunlar cinsel istismar, fiziksel, duygusal istismar, çocuk işçiliği, mülteci çocuklar ile ilaç bağımlılığına ilişkin konularda çocukların korunmasını sağlayan haklardır (Uğurlu ve Aksoy, 2014). Çocukların insan haklarına sahip olmadığı bir toplumda, yetişkinler de insan haklarından nasiplerini alamayacaklardır. Çocuk Hakları Sözleşmesi'nde anılan çocuk hakları insan haklarının hem mayasıdır, hem dinamosudur (Serozan, 2107).

Birleşmiş Milletler Çocuk Haklarına Dair Sözleşme; din, dil, ırk, cinsiyet ayırımı gözetmeksizin bütün çocukların haklarını tanımlamaktadır. On sekiz yaş altı bütün çocukların bu ayırımlar gözetilmeksizin, yüksek menfaatleri gözetilerek tüm gereksinimleri karşılanmak zorundadır. Devletler; çocukların haklarının korunmasından ve çocuklara verilen haklara saygı gösterilmesinden yükümlüdürler.

\subsection{2. Çocuk Haklarının Kullanılmasına Ilişsin Avrupa Sözleşmesinde Çocuk Hakları}

Çocuk Haklarının Kullanılmasına İlişkin Avrupa Sözleşmesi 25 Ocak 1996 tarihinde Strasbourg'da imzalanmış olup 1 Temmuz 2000 tarihinde yürürlüğe girmiştir. Türkiye sözleşmeyi 9 Haziran 1999 tarihinde imzalamış ve 18 Ocak 2001 tarihinde Türkiye Büyük Millet Meclisi'nde onaylamıştır. 4620 Sayılı Onay Yasası 1 Şubat 2001 gün ve 24305 Sayılı Resmi Gazete 'de yayımlanmıştır. Sözleşmenin önsöz kısmında çocukların haklarının ve çocukların yüksek çıkarlarının geliştirilmesi, bunun için çocukların gerekli bilgiyi almalarını sağlamak hususlarında t araf devletlerin mutabık kaldıkları belirtilmiştir. Sözleşmenin 1. maddesi "Bu sözleşme on sekiz yaşına ulaşmamış çocuklara uygulanır" hükmüyle çocukluk yaşını on sekiz olarak kabul etmiştir. Sözleşmenin bu hükmüyle on sekiz yaşından aşağı olmamak şartıyla, taraf devletlere çocukluk yaşının üst sınırı için farklı bir yaş belirleme serbestisi tanındığı anlaşıımaktadır (Balo, 2005; TBMM, 2001).

Çocuk Haklarının Kullanılmasına Dair Avrupa Sözleşmesinin 3 ve 6. Maddeleri, iç hukuk tarafından yeterli anlama yeteneğine sahip olduğu kabul edilen çocuklara kendilerini ilgilendiren davalarda görüşlerini ifade etmeye olanak tanınmasını ve beyan etmiş oldukları görüşlere gereken önemin verilmesi gerektiğini öngörmektedir (TBMM, 2001).

Çocuk Haklarının Kullanılmasına İlişkin Avrupa Sözleşmesi; çocukların özellikle kendilerini ilgilendiren ailevi işlemlerde haklarının korunmasını, çocukların şahıslarıyla ilgili alınan, kişilik haklarını ilgilendiren davalara katılmak, bilgi edinme hakkı tanınarak görüş 
Hüseyin SERIN

ve isteklerinin usulüne uygun bir şekilde alınması gerektiği, özel yaşantısı, onur ve itibarının yüksek düzeyde korunmasına yönelik içerikten oluşmaktadır. Çocuk haklarıyla ilgili uluslararası mevzuatla beraber Türk Hukuk sisteminde de düzenlemeler yapılmıştır.

\section{2. Çocuk Hakları Konusunda Türk Hukukunda Gelişmeler}

Türk Hukuk Sisteminde, çocuk haklarıyla ilgili olarak; Anayasa, Türk Medeni Kanunu, Türk Ceza Kanunu, Çocuk Koruma Kanunu, Çocukları Muzır Neşriyattan Koruma Kanunu gibi düzenlemeler yapılmıştır.

\subsubsection{Anayasası}

Anayasa, özel bir formaliteyle ve prosedürle oluşturulan ve özel bir yürürlük güvencesiyle pekiştirilen devletin temel yapısını kurucu bir hukuksal yasadır. Anayasa yasaların anası olarak kurallar hiyerarşisinin doruk noktasında yer alır. Tüm kurallar ve yargılar, işlemler ve eylemler Anayasa'ya uygun olmalıdır. Anayasa'da doğrudan doğruya çocukların korunmasıyla ilgili bir kurala rastlanmaz (Serozan, 2017).

Türkiye Cumhuriyeti Anayasası'nın (1982) 41, 50 ve 61. maddelerinde çocukların haklarına yönelik bazı özel hükümler yer almaktadır. Bu maddelerle birlikte, Anayasa'da kişi hakları ve ödevleri bölümünde yer alan haklardan çocuklar da özel bir yaş sınırlaması olmadığı sürece yetişkin bireyler gibi yararlanırlar.

Anayasanın 41. maddesine göre "Devlet, ailenin huzur ve refahı ile özellikle ananın ve çocukların korunması ve aile planlamasının öğretimi ile uygulanmasını sağlamak için gerekli tedbirleri alır, teşkilâtı kurar. Her çocuk, korunma ve bakımdan yararlanma, yüksek yararına açıkça aykırı olmadıkça, ana ve babasıyla kişisel ve doğrudan ilişki kurma ve sürdürme hakkına sahiptir. Devlet, her türlü istismara ve şiddete karşı çocukları koruyucu tedbirleri alır."

Anayasanın 50. maddesi gereği "Küçükler ve kadınlar ile bedenî ve ruhî yetersizliği olanlar çalışma şartları bakımından özel olarak korunurlar."

Anayasanın 61. maddesine göre "Devlet, korunmaya muhtaç çocukların topluma kazandırılması için her türlü tedbiri alır. Bu amaçlarla gerekli teşkilat ve tesisleri kurar veya kurdurur."

Küçüklerin yargılanmalarının nasıl yapılacağıyla ilgili Anayasanın 141. maddesinde "Küçüklerin yargılanması hakkında kanunla özel hükümler konulur." denilmektedir. 
1982 Anayasasının çocukları ilgilendiren ilgili maddelerine bütüncül olarak bakıldığında, devletin tüm vatandaşlarını korumakla yükümlü olmakla beraber çocukların karşılaşabileceği her türlü olumsuz durumlara karşı gerekli tedbirlerin alınması, korunması durumuna da vurgu yapıldığı görülmektedir.

\subsubsection{Türk Medeni Kanunu}

Medeni Kanun, sosyal konumu ne olursa olsun, tüm bireylerin, doğumlarından ölümlerine, hatta doğum öncesinden ölüm sonrasına değin tüm kişi varlığı ve mal varlığı ilişkilerini düzenler. Çocuk hukuku denilince akla kamu hukuku alanında çocuğun korunmasından ve uluslararası çocuk haklarından önce medeni hukuk alanında çocuğun hakları, korunması ve sorumluluğu gelir. Özellikle çocuğun anne ve babasıyla olan velayet ilişkileri özel bir ağırlık taşımaktadır (Serozan, 2017).

Türkiye'de çocuk haklarının gelişimini 1926 yılında yürürlüğe giren Medeni Kanun ile başlatmak yanlış olmayacaktır. Yıllar içerisinde günün şartlarına göre diğer kanunlarda olduğu gibi Medeni Kanun'da da değişikler meydana gelmiştir. 4722 sayılı Yeni Türk Medeni Kanunu Türkiye Büyük Millet Meclisi tarafından 22 Kasım 2001'de kabul edilmiş ve 1 Ocak 2002 tarihinde yürürlüğe girmiştir.

4722 sayılı Yeni Türk Medeni Kanunu'nun 28. maddesine göre "Kişilik, çocuğun sağ olarak tamamıyla doğduğu anda başlar ve ölümle sona erer. Çocuk hak ehliyetini, sağ doğmak koşuluyla, ana rahmine düştüğü andan başlayarak elde eder."

Türk Medeni Kanunu'nun 185. maddesinde “Eşler, aile birliğinin mutluluğunu elbirliğiyle sağlamak ve çocukların bakımına, eğitim ve gözetimine beraberce özen göstermekle yükümlüdürler" denilmektedir.

Çocuğun korunmasını düzenleyen 346. maddeye göre "Çocuğun menfaati ve gelişmesi tehlikeye düştüğü takdirde, ana ve baba duruma çare bulamaz veya buna güçleri yetmezse hâkim, çocuğun korunması için uygun önlemleri alır."

Çocuğun yerleştirilmesini düzenleyen 347. maddeye göre ise; “Çocuğun bedensel ve zihinsel gelişmesi tehlikede bulunur veya çocuk manen terk edilmiş halde kalırsa hâkim, çocuğu bir aile yanına veya bir kuruma yerleştirebilir" denilmektedir.

Türk Medeni Kanununda ifade bulan bu maddeler ile çocukların ailelerinden kaynaklı ihmal ve istismardan korunup kollanmasının amaçlandığı görülmektedir. İhmal ve istismarın yaşanması durumunda yapılması gerekenler belirtilerek, çocukların karşılaşabilecekleri zararlarının minimize edilmesi ya da ilerde karşılaşılabilecek olumsuz durum ve davranışların önlenmesi amacı bu maddelerde belirtilmektedir. 
Hüseyin SERIN

\subsubsection{Türk Ceza Kanunu}

Bireye ve topluma verdiği zarar özel hukukun basit zarar giderim ya da eski hale iade yaptırımlarıyla telafi edilemeyecek ve yarattığı tehlike de yine özel hukukun önleyici kaçınma yaptırımıyla telafi edilemeyecek çapta eylemler daha ağır ve etkin kamusal ceza yaptırımına veya güvenlik önlemine tabi tutulur; bu gibi nitelikli eylemler ceza hukukunun konusuna girerler. Çocuğun kötü muameleye karşı korunması konusunda Ceza Kanunu kuralları iyi bilinmelidir (Serozan, 2017).

5237 sayılı Yeni Türk Ceza Kanunu 1 Haziran 2005 tarihinde yürürlüğe girmiştir. Türk Ceza Kanunu'nun genel hükümlerinde tanımlar başlıklı 6/b maddesinde, çocuğun tanımı "Henüz on sekiz yaşını doldurmamış kişi" olarak yapılmıştır. Bu maddenin gerekçesinde, Birleşmiş Milletler Çocuk Haklarına Dair Sözleşme hükümleri göz önüne alınarak çocukluk yaşı sınırının on sekiz yaş olarak kabul edildiği belirtilmiştir.

Türk Ceza Kanunu'nun kötü muamele başlığı altında yer alan 232. maddesine göre; "Aynı konutta birlikte yaşadığı kişilerden birine karşı kötü muamelede bulunan kimse, iki aydan bir yıla kadar hapis cezası ile cezalandırılır. İdaresi altında bulunan veya büyütmek, okutmak, bakmak, muhafaza etmek veya bir meslek veya sanat öğretmekle yükümlü olduğu kişi üzerinde, sahibi bulunduğu terbiye hakkından doğan disiplin yetkisini kötüye kullanan kişiye, bir yıla kadar hapis cezası verilir" denilmektedir.

Aile hukukundan kaynaklanan yükümlülüğün ihlali başlığı altında yer alan 233. maddeye göre; “ Aile hukukundan doğan bakım, eğitim veya destek olma yükümlülüğünü yerine getirmeyen kişi, şikâyet üzerine bir yıla kadar hapis cezası ile cezalandırılır. Velayet hakları kaldırılmış olsa da itiyadi sarhoşluk, uyuşturucu veya uyarıcı maddelerin kullanılması ya da onur kırıcı tavır ve hareketlerin sonucu maddi ve manevi özen noksanlığı nedeniyle çocuklarının ahlak, güvenlik ve sağlığını ağır şekilde tehlikeye sokan ana veya baba, üç aydan bir yıla kadar hapis cezası ile cezalandırılır. "

Çocuğun ticari amaçla sömürülmesi suçunu işleyenlerle ilgili Türk Ceza Kanunu'nda bazı maddeler yer almaktadır. Bu maddelerden biri de müstehcenlik başlığıyla yer alan 226. maddedir. Bu maddeye göre; "Bir çocuğa müstehcen görüntü, yazı veya sözleri içeren ürünleri veren ya da bunların içeriğini gösteren, okuyan, okutan veya dinleten kişi, altı aydan iki yıla kadar hapis ve adlî para cezası ile cezalandırılır. Müstehcen görüntü, yazı veya sözleri basın ve yayın yolu ile yayınlayan veya yayınlanmasına aracılık eden kişi altı aydan üç yıla kadar hapis ve beş bin güne kadar adlî para cezası ile cezalandırılır. Müstehcen görüntü, yazı veya sözleri içeren ürünlerin üretiminde çocukları, temsili çocuk görüntülerini veya çocuk gibi görünen kişileri kullanan kişi, beş yıldan on yıla kadar hapis ve beş 
bin güne kadar adlî para cezası ile cezalandırılır. Bu ürünleri ülkeye sokan, çoğaltan, satışa arz eden, satan, nakleden, depolayan, ihraç eden, bulunduran ya da başkalarının kullanımına sunan kişi, iki yıldan beş yıla kadar hapis ve beş bin güne kadar adlî para cezası ile cezalandırılır."

\subsection{4. Çocuk Koruma Kanunu}

5395 Sayılı Çocuk Koruma Kanunu, korunma ihtiyacı içinde bulunan çocuklar hakkında alınacak "koruyucu ve destekleyici tedbirler" ile suça sürüklenen ve ceza sorumluluğu olmayan çocuklar hakkında uygulanacak "güvenlik tedbirleri "nin usul ve esaslarını ve çocuk mahkemelerinin kuruluş ve yetkilerini kapsamaktadır. Kanunun amacı korunma ihtiyacı olan veya suça sürüklenen çocukların korunmasını, haklarının ve esenliklerinin güvence altına alınmasını sağlamaktır. Kanun normal çocuklarla yani teknik anlamda korunma ihtiyacı içinde bulunmayan ve suça sürüklenmemiş olan çocuklarla ilgilenmemektedir (Akyüz, 2016).

395 Sayılı Çocuk Koruma Kanununun (ÇKK) "Tanımlar" başlıklı 3. maddesinde kanunda yer alan terimler tanımlanmıştır. ÇKK'nin 3. maddesinde "Daha erken yaşta ergin olsa bile, on sekiz yaşını doldurmamış kişi" çocuk sayılmıştır. Bu kanunda ifade edilen "daha erken yaşta ergin olsalar bile" ibaresi oldukça önemlidir. Türk Medeni Kanununun 11. ve 12.maddelerinde evlenme veya erginlik kararıyla on sekiz yaşından önce çocukların ergin olması mümkündür. ÇKK'nin çocuğu bu şekilde tanımlamasıyla çocuklar daha erken yaşta ergin olsalar bile on sekiz yaşını dolduruncaya kadar çocuk sayılacaklar ve dolayısıyla ceza sorumluluğu bakımından ÇKK'ye tabi olacaklardır (Artuç ve Gedikli, 2007). Çocuk Koruma Kanunu'nda, çocuklarla ilgili yürütülecek tüm işlemlerle ilgili çocuğun yararına öncelik verilmesi ilkesi benimsenmiştir.

Çocuk Koruma Kanunu'nun Koruyucu ve Destekleyici Tedbirler başlığıyla yer alan 5 . maddesinde "koruyucu ve destekleyici tedbirler, çocuğun öncelikle kendi aile ortamında korunmasını sağlamaya yönelik danışmanlık, eğitim, bakım, sağlık ve barınma konularında alınacak tedbirlerdir. Bunlardan;

a) Danışmanlık tedbiri, çocuğun bakımından sorumlu olan kimselere çocuk yetiştirme konusunda; çocuklara da eğitim ve gelişimleri ile ilgili sorunlarının çözümünde yol göstermeye,

b) Eğitim tedbiri, çocuğun bir eğitim kurumuna gündüzlü veya yatılı olarak devamına; iş ve meslek edinmesi amacıyla bir meslek veya sanat edinme kursuna gitmesine veya meslek sahibi bir ustanın yanına yahut kamuya ya da özel sektöre ait işyerlerine yerleştirilmesine, 
Hüseyin SERIN

c) Bakım tedbiri, çocuğun bakımından sorumlu olan kimsenin herhangi bir nedenle görevini yerine getirememesi halinde, çocuğun resmî veya özel bakım yurdu ya da koruyucu aile hizmetlerinden yararlandırılması veya bu kurumlara yerleştirilmesine,

d) Sağıı tedbiri, çocuğun fiziksel ve ruhsal sağlığının korunması ve tedavisi için gerekli geçici veya sürekli tıbbî bakım ve rehabilitasyonuna, bağımlılık yapan maddeleri kullananların tedavilerinin yapılmasına,

e) Barınma tedbiri, barınma yeri olmayan çocuklu kimselere veya hayatı tehlikede olan hamile kadınlara uygun barınma yeri sağlamaya, yönelik tedbirdir " denilmektedir.

\subsubsection{Küçükleri Muzır Neşriyattan Koruma Kanunu}

1117 Sayılı Küçükleri Muzır Neşriyattan Koruma Kanunu ile 18 yaşından küçük bireylerin maneviyatı açısından sakınca teşkil edebilecek özellikle cinsel dürtülere yönelik pornografik basılı yayın reklamı, dağıtım ve sergilenmesi önemli sınırlamalara tabi tutulmuştur. Bu kanun gereği oluşturulan ilgili kurul, basılmış eserlerin küçükler için muzır olup olmadığı hususunda yapacağı incelemede, 1739 sayılı Milli Eğitim Temel Kanunu'ndaki genel amaç ve temel ilkeleri göz önünde bulundurmak zorundadır.

Uluslararası mevzuatla beraber ulusal hukuk metinlerinde de başta normlar hiyerarşisinde en tepede yer alan Anayasa olmak üzere, Türk Ceza Kanunu, Türk Medeni Kanunu, Çocuk Koruma Kanunu ve diğer kanunlarımızda çocukların korunmasına ilişkin önemli hükümler yer almaktadır.

\section{5. Çocuğun Kişilik Haklarının Sosyal Medya Araçları Üzerinden İhlal Edilmesi}

Kişilik hakkı kavramı, bireyin kişiliğini oluşturan hayat, vücut bütünlüğü, onuru, şeref ve haysiyeti, sır alanı, ad, resim, fotoğraf, görüntü, ses, özel hayatın gizliliği, ekonomik özgürlük ve diğer kişisel değerler gibi maddi ve manevi değerlerin tümü üzerinde sahip olmuş olduğu hak seklinde tanımlanabilir (Dural ve Öğüz, 2016; Gönen, 2011; Helvacı, 2001; Serozan, 1977; Özel, 2004; Zeytin ve Ergün, 2018).

Kişilik hakkının önemli bir içeriğini, kişinin onur, şeref ve haysiyeti oluşturur. Şeref ve haysiyet, kişinin içinde bulunduğu toplumun gerekli saydığı ahlâkî niteliklere sahip olduğu ya da böyle kabul edildiği için bireye verilen değeri ifade eder (Dural ve Öğüz, 2016).

Kişinin özel hayatı, üzerinde tasarrufta bulunma hakkına sahip olması nedeniyle diğer başka kişiler tarafından bilinmesini arzu etmediği ve hukuk tarafından da korunması 
ve gizliliği temel bir hak olarak görülen faaliyetlerin oluşturmuş olduğu bir alan olarak tanımlanabilir. Bireylerin toplum psikolojisi içinde yaşamlarını sürdürmelerine rağmen diğer başka kişilerin müdahil olmalarını istemedikleri ve belki de bu nedenle de sahip oldukları arasında en çok değer verdikleri bu özel alanlarına bilgi iletişim teknolojilerinde yaşanan hızlı değişim ve gelişmeler doğrultusunda çok rahat bir şekilde müdahale edilebilmeye ve tüm bireylerden gizledikleri ve herkesin de saygı duymasını istedikleri bu alana dahil değerleri geri dönülemez şekilde ihlâl edilebilmektedir (Özdemir, 2009). Sosyal medya platformları kişilik hakkı ihlallerini arttıran bir etkiye sahiptir.

Kişinin önemli kişilik değerlerinden biri de resmi ve sesidir. Resim ve ses kişinin ayırt edici özelliklerindendir. Resim ve ses kişilik değeri olarak kişilik hakkı kapsamında korunmaktadır. Bu kapsamda hiç kimsenin rızası dışında sesinin değiştirilerek dahi olsa kaydedilmesi, resminin fotoğraf makinesi, video kayıt cihazları gibi teknik araçlarla kaydedilmesi, fırça ve boya kullanarak çizilmesi, karikatürize edilmesi, heykelinin yapılması vb. şekilde resminin yansımalarının oluşturulması, resme ve sese ilişkin bu verilerin kullanılması, satılması, yayımlanması, teşhiri ve paylaşımı yapılamayacaktır (Helvacı, 2001).

Çocuğun onuru ve saygınlığı; onu küçük düşürebilecek eylemlerle, karalayıcı, aşağılayıcı, ve horlayıcı görüntü, ses ve resimlerinin başkaları tarafından paylaşılıp açığa vurulmasıyla ihlal edilebilir. Onur ve saygınlığının bu hareketlerle çiğnenmesi çocuğun özel yaşamının gizliliğinin ayaklar altına alınmasına sebep olabilir (Serozan, 2017).

Bireyin insan olmasından kaynaklı "insan onuru"nun temelinde yatan özel yaşamın gizliliği hakkı, sosyal medya aracılığıyla çeşitli biçimlerde ihlal edilebilmektedir. Bu ihlaller; etiketleme, görsel işitsel malzeme paylaşımı özelliğinin kullanımı veya paylaşımların izinsiz bir şekilde aktarılması şeklinde gerçekleşebilmektedir (Binark ve Bayraktutan 2013).

Çocuğun; fotoğraf, ses ve görüntülerinin ebeveyn ve öğretmenleri tarafından sosyal medya araçları üzerinden izinsiz paylaşılması çocuğun kişilik haklarını, özel hayatını ihlal etmektedir. Çocuğun da hak ehliyetine sahip olduğu düşünüldüğünde paylaşımı yapılan resim, ses ve görüntülere ilişkin daha sonrasında rıza göstermemesi gündeme gelebilir. Dolayısıyla da çocukların medeni haklarını kullanma ehliyetine sahip oldukları yaşa geldiklerinde ana ve babalarının, öğretmenlerinin veya diğer üçüncü kişilerin yayınlamış oldukları resim, ses ve görüntülere karşı hukuki yollara başvurmaları gündeme gelebilir.

2018 yılının başlarında 16 yaşındaki bir çocuk İtalya'da kendi rızası dışında sosyal paylaşım ağlarında fotoğraflarını paylaşan annesine karşı açmış olduğu davayı kazanmıştır. Dava neticesinde mahkeme, çocuğun kişilik haklarının korunması amacıyla şikâyete konu olan paylaşımların silinmesine hükmetmiştir. Annenin gelecekte benzer davranışlar- 
Hüseyin SERIN

da bulunması durumunda da önleyici tedbir olarak on bin Euro tazminat ödemesine karar verilmiştir (BBC, 2018).

Benzer bir şekilde Avusturya'da 18 yaşını henüz doldurmuş olan bir kadın, kendi rızası dışında yatak odası ve tuvalet gibi mahrem alanlar dahil olmak üzere özel fotoğraflarını çekip Facebook üzerinden 700 kadar arkadaşıyla paylaşan ebeveynleri hakkında maddi ve manevi tazminatla cezalandırılmaları için dava açmıştır. Bu dava dilekçesinde ayrıca fotoğrafların ilgili platformdan kaldırılmasıyla ilgili talepte bulunmuştur (Usatoday, 2016).

İtalya'nın Mantova kentinde yerel mahkeme, bir anneye, çocuklarıyla ilgili paylaşmış olduğu fotoğrafları sosyal medya platformlarından kaldırması yönünde karar bildirmiştir. Reşit olmayan kızı adına Facebook hesabı açıp paylaşımlarda bulunan başka bir annenin hesabının iptal edilmesiyle ilgili benzer bir karar 2013 yılında alınmıştır. Alınan bu kararların küçük yaştaki çocukların özel hayatın gizliliğinin korunması ve toplum hayatı içindeki imajının zedelenmemesi ilkesine dayandırıldığı görülmektedir (BBC, 2018).

Ebeveynlerin önemli bir kısmı sosyal medya platformlarında çocuklarına ait video, fotoğraf ve kişisel bilgi paylaşımında bulunabilmektedirler. Sosyal medya araçlarını maddi kazanç elde etmek amacıyla kullanan ebeveynlerin paylaşımları da ayrıca farklı bir durum yaratmaktadır. Özellikle son yıllarda Youtube üzerinden çocuklarıyla ilgili içerik paylaşımında bulunan annelere "youtubermoms" veya "youtuberanneler" denilmektedir. Aynı şekilde Instragram'da çocuk odaklı içerikler paylaşan anneler "Instamoms", "Instagramanneleri" kavramıyla anılmaktadır. Bu platformlarda çocuklarla ilgili paylaşım yapan anneler farklı etiketler kullanarak yapmış oldukları paylaşımların görünürlüklerini arttırabilmektedirler. Çeşitli sosyal medya platformlarında, ailelerinin yönlendirmesi ve teşvikiyle ünlü olup para kazanan çok sayıda çocuk bulunmaktadır. Çocuğunu sanal dünyanın zararlarından ve bu mecralarda gerçekleşebilecek istismarlardan koruması gereken ebeveynler, çoğu zaman bilinçli veya bilinçsiz bir şekilde istismarı bizzat kendileri gerçekleştirmekte, kendilerini koruma ve kollamada yetersiz olan çocukları teşhir ederek kişilik haklarının ihlal edilmesine yol açabilmektedirler (Atalay, 2019).

Çocuklar yetişkinlere göre daha zayıf ve korunmaya muhtaç oldukları için her türlü küçük düşürücü ve zarar verici davranışlar onların manevi bütünlüğünü zedeleyebilmektedir. Çocuğunun kişilik haklarının saldırıya uğrayıp ihlal edilmesi ana baba, öğretmen ya da diğer başka kişiler tarafından gerçekleştirildiğinde Türk Medeni Kanununun 23 ve 24 . maddeleri ile Türk Borçlar Kanunu'nun 58. maddesine aykırılık teşkil edecektir. Bu davranışların süreklilik arz etmesi durumunda çocuğun psiko-sosyal gelişimini olumsuz bir şekilde etkileyeceği için çocuğun korunması düşüncesinden hareketle mahkeme tarafından velayetin kaldırılmasının yanı sıra tazminat ve diğer farklı tedbirlere başvurulabilir. 
Nitekim Türkiye'de 200 bine yakın takipçisi olan ünlü blogger anne hakkında eşi tarafından açılan davada; annenin, çocuklarının video ve fotoğraflarını sosyal medya platformlarında paylaşarak kendi tanınırlığı ve takipçi sayısını artırma gayretinde olduğu, paylaşımların herkese açık şekilde yapıldığı, kamuya sunulduğu ve çocuklarının istismar edilmesine davetiye çıkardığı iddia edilmiştir. Çocukların babası velayetlerinin kendisine verilmesi talebinde bulunmuştur. Babanın taleplerini haklı bulan mahkeme, davanın sonuçlanmasını beklemeden aldığı ara kararla, çocukların velayetlerinin babaya verilmesine karar vermiş ve annenin çocuklarının fotoğraflarını sosyal medya üzerinden yayınlanmasına yasak getirmiştir (Ntv, 2017).

Ebeveynlerin çocukları ile ilgili bilgi iletişim araçları üzerinden yapacakları paylaşımlarda çocuğun onur, şeref ve haysiyetini ihlal edecek yaklaşımlardan uzak durması gerekmektedir. Uygunsuz bir şekilde fotoğraf, video veya seslerinin paylaşılması çocuğun arkadaş çevresinde küçük düşürülüp rencide olmasına ve arkadaşları arasında var olan saygınIığının zedelenmesine sebep olabilmektedir. Bu da çocuğun psiko-sosyal gelişimi açısından ciddi sorunlar oluşturabilmektedir. Ayrıca çocuğun fotoğraf ve videolarının diğer üçüncü kişilerin de rahat ulaşabilecekleri bir şekilde paylaşılıp erişime açık olması daha da büyük sorunlara sebep olabilmektedir. illk olarak üçüncü kişiler fotoğraf ve videoları ele geçirdiğinde fotoğraflar üzerinde bazı değişiklikler yapıp daha çok uygunsuz içerikten oluşan internet siteleri üzerinde paylaşım yaparak çocuğun kişilik hakkı üzerinde telafisi mümkün olmayan önemli sorunlara sebep olabilmektedir. Böyle bir durumun ortaya çıkması hem çocuğun kişilik hakkına bir tecavüz oluşturabilmekte hem de kötü niyetli kişiler tarafından çocukların değişik şekillerde istismar edilmesine zemin oluşturabilmektedir. Bu konuda ebeveynlerden beklenen çocukların fotoğraf ve görüntülerini içeren videolarını paylaşırken gizlilik ayarları konusunda çok özenli davranmaları, diğer üçüncü kişilerin çocuklarla ilgili yapılan kişisel paylaşımlara erişlerinin önüne geçmelidir. Diğer başka kişilerin paylaşımına açık olmasa bile kendi arkadaş çevresinde de çocuğun saygınlığını ve onurunun küçük düşürülmesine sebebiyet verebilecek paylaşımların yapılmamasına özen göstermek önem arz etmektedir (Akdi, 2016).

Çocuklarla ilgili izinsiz paylaşımların yapılması suç teşkil edeceğinden, ebeveynlerin ve öğretmenlerin bu tür paylaşımlardan uzak durmasını gerektirmektedir. Nitekim internette izinsiz fotoğraf, video yayınlamak, Türk Ceza Kanunun 136. maddesi gereğince hapis cezasını gerektirmektedir. Bu madde hükmüne göre, kişisel verileri hukuka aykırı bir şekilde ele geçiren, bir başkasına veren ya da yayan kişi hakkında 2 yıldan 4 yıla kadar hapis cezasına hükmolunur denilmektedir.

Dijital araçların yoğun kullanımıyla beraber yeni bir hak kavramı daha ortaya çıkmıştır. Bu hakka "Unutulma Hakkı" denilmektedir. Unutulma hakkı, yetişkinleri ilgilendirdiği kadar korunmaya daha fazla ihtiyacı olan çocukları da ilgilendirmektedir. Çocuk hakları 
Hüseyin SERIN

bağlamında unutulma hakkını, çocuğun dijital ortamlarda yer alan ve başka fertlerin erişim ve takibini istemediği kendisine ait; ses, fotoğraf, resim, görüntü ve diğer şahsi verilerinin ortadan kaldırılmasını, sanal dünyada, sosyal medya platformlarında unutulmasını isteme hakkı şeklinde tanımlayabiliriz.

Bu bağlamda, unutulma hakkının, kişinin geçmişi ile geleceğini serbestçe şekillendirme dolayısıyla dijital dünyada kişisel verilerini özgür bir şekilde kullanma veya kullandırmama isteğinin doğal bir sonucu olduğunu, unutulma hakkına aykırı olarak bireyin başka kişilerin bilmesini istemediği şahsi verilerinin kendi rızası olmadan internet ortamında uzunca bir süre ve gereksiz biçimde yer almasının ve silinmemesinin, kamuoyunda hakkında şüphe ve tereddütlerin doğmasına neden olabileceğini dolayısıyla onurlu bir şekilde yaşamını sürdürmesine engel teşkil edebileceğini belirtebiliriz (Akgül, 2015).

Yapılan araştırmalar, içinde bulunduğumuz dijital çağda kullanımı her geçen gün artan sosyal medya platformlarının, okulların önemli unsurları arasında olan öğrenci ve öğretmenleri sosyal ağlarda aktif katılımcılığa sevk ettiğini, öğrenci - öğretmen arasındaki etkileşimi hızla artırdığını göstermektedir. Öğretmenler sosyal medya platformlarında öğrencileriyle arkadaş olmakta ve iletişim kurmaktadır. Ancak bu ağlar üzerinden iletişimlerini nasıl bir çerçeveye oturtmaları gerektiği konusu eğitimciler tarafından tartışılmakta ve sosyal medya araçları üzerinden öğrenci - öğretmen arkadaşlığı konusu büyük bir soru işareti olarak zihinleri meşgul etmektedir. Bazı ülkelerde sosyal medya platformlarında öğretmen ve öğrenci etkileşimine yönelik birçok araştırma, tartışma, vaka olumluolumsuz yönleriyle ele alınıp tartışılmaktadır (Asterhan ve Rosenberg, 2015; Fleming, 2014; Gerlach, 2014; Grisham, 2014; Kuehn, 2012; Lucas, 2009; Lytle, 2011; Mazer, Murphy ve Simonds, 2007; Puzio, 2013; Rutledge, 2011; Salazar, 2014; akt. Cemaloğlu ve Bıçak, 2015).

Okulda bulunan yöneticiler, öğretmenler, öğrenciler, diğer tüm çalışanlar hatta okul dışı önemli paydaşlar arasında yer alan veliler arasında hoşgörüye, sevgiye, saygıya ve anlayışa dayanan iki yönlü bir iletişim kurulduğunda; okulda insan hak ve özgürlüklerine saygılı bir ortam oluşturulduğunda öğrenciler insan hakları, özgürlükleri ve vatandaşlık konusunda öğrendiklerinin okul ikliminde hayata geçmiş olduğunu göreceklerdir. Bundan dolayıdır ki okullarda insan hak ve özgürlükleri, vatandaşlık alanında öğretilenler ile uygulamalar arasında tutarlık sağlanmalıdır. Böylece, okulda insan haklarına duyarlı ve saygılı bir toplum oluşturma amacına hizmet etmiş olacaktır (Kepenekçi, 2008). Tutarlıığın sağlanması adına, okul çalışanları, sosyal medya araçlarını kullanırken çocuğun kişilik haklarını ihlal edecek davranışlardan uzak durmalıdırlar. 
Kendi haklarının bilincinde olan demokratik bireyler yetiştirmek eğitim kurumlarının başlıca görevlerinden birisidir. Eğitim kurumlarında öncelikle demokratik bir ortam oluşturulmalıdırlar. Bu ortamın sağlanmasında ise en önemli görevler okul yöneticileri ve öğretmenlere düşmektedir. Çünkü okul yöneticileri ve öğretmenler öğrenciler için birincil modellerdir. Buna rağmen okullarda anti demokratik uygulamalar sürebilmektedir. Okullarda yönetici ve öğretmenlerin, zaman zaman çocuk haklarını ihlal ettikleri ya da bu hakların uygulamaya geçirilemediği görülmektedir (Gömleksiz vd., 2008).

Türkiye'de, 7 Mart 2017 tarihinde Millî Eğitim Bakanlığı tarafından yayınlanan, 2975829 sayılı 2017-12 nolu "Okullarda Sosyal Medyanın Kullanılması" konulu genelge ile Türkiye Cumhuriyeti Anayasası, Birleşmiş Milletler Genel Kurulu tarafından kabul edilen 20.11.1989 tarihli Çocuk Haklarına Dair Sözleşme, 1739 sayılı Milli Eğitim Temel Kanunu ve 5237 sayılı Türk Ceza Kanununa vurgu yapılmış bu genelge ile Sosyal medya platformları aracılığıyla öğrenci fotoğrafları, öğrenci videoları başta olmak üzere yapılan paylaşımlara ilişkin açıklık getirilmiştir. Bu genelge gereği öğrencilerin fotoğraf, video ve ses kayıtlarının internette, sosyal medya platformlarında hukuka aykırı olacak bir şekilde paylaşılması durumunda, gerekli hukuki işlem başlatılacağı ifade edilmiştir. Ayrıca internette öğrenci fotoğrafları paylaşmak, sınıf ortamında çekilen öğrenci videolarını sosyal medya araçları ile paylaşmak, hukuka aykırı ise gerekli soruşturma yapılacağı belirtilmiştir (MEB,2017).

Milli Eğitim Bakanlığı Teftiş Kurulu Başkanlığı tarafından, okul ortamında sosyal ağlar üzerinden ses, görüntü ve video paylaşımı konusunda yaşanan tereddütlerin giderilmesi ile ilgili bir açıklama metni yayınlanmıştır. Bu açıklamada: "Öğrencilerin kişisel gelişimleri ile psikolojik ve sosyal gelişimlerine olumsuz etki yapacak ve bununla birlikte kişilik haklarını ihlal edecek ses, görüntü ve video kayıtlarının sosyal ağ ortamlarında paylaşılması konusunda; Anayasa, uluslararası sözleşmeler, yasal ve idari düzenlemeler ile Türk Millî Eğitiminin genel amaç ve temel ilkelerinin dikkate alınması ve bu kapsamda, gerekli tedbirlerin oluşturulması amaçlanmıştır. Bu bilgiler ışığında, eğitim-öğretim ile ilgili kamuoyu ile paylaşılmasında fayda görülen, örnek uygulamaları içeren "ses, görüntü ve video kayıtlarının” öğrenci velilerinden izin alınarak, Resmi okul/kurum web sitelerinde paylaşılmasında herhangi bir sakınca bulunmamaktadır. "denilmiştir (http://tkb.meb.gov.tr/www/ses-goruntu-ve-video-paylasimi/icerik/69).

Sosyal medyada kişisel verilerin korunması kapsamında, Almanya'da da öğretmenler için bir kısıtlama getirilmiştir. Almanya'nın Baden-Württemberg eyaleti Kültür Gençlik ve Spor Bakanlığı, yayınladığı bir genelge ile sosyal medya platformlarını kullanan öğretmenleri birtakım kurallara bağladığı görülmektedir. Yayınlanan genelge ile kişisel verilerin korunması ilkesi doğrultusunda sosyal medya platformlarında öğretmenlerin görevlerine ilişkin veri paylaşımı yasaklanmıştır. İster öğretmenler arasında olsun isterse de öğretmen 
Hüseyin SERIN

ile öğrenciler arasında olsun, sosyal medyada araçları aracılığıyla gerçekleşen her türlü iletişimin bu kapsama girdiği belirtilmiştir. Bu genelgeye göre, Instagram, Twitter, Facebook, Studi VZ, Google+, Snapchat gibi sosyal medya araçları aracılığıyla ders araç ve gereçleri paylaşmak, çalışma grupları kurmak mümkün olmayacak (https://www.dw.com/tr/öğretmenlere-facebook-yasağı/a-16968462).

Türkiye'de internet uygulamalarını düzenleyen 5651 sayılı İnternet Ortamında YapıIan Yayınların Düzenlenmesi ve Bu Yayınlar Yoluyla İşlenen Suçlarla Mücadele Edilmesi Hakkında Kanunu'nun 9/1. maddesinde "Internet ortamında yapılan yayın içeriği nedeniyle kişilik haklarının ihlal edildiğini iddia eden gerçek ve tüzel kişiler ile kurum ve kuruluşlar, içerik sağlayıcısına, buna ulaşamaması hâlinde yer sağlayıcısına başvurarak uyarı yöntemi ile içeriğin yayından çıkarılmasını isteyebileceği gibi doğrudan sulh ceza hâkimine başvurarak içeriğe erişimin engellenmesini de isteyebilir." ve aynı maddenin 3. fıkrasında "Internet ortamında yapılan yayın içeriği nedeniyle kişilik hakları ihlal edilenlerin talepleri doğrultusunda hâkim bu maddede belirtilen kapsamda erişimin engellenmesine karar verebilir." şeklinde bir düzenleme bulunmaktadır.

\section{Tartışma, Sonuç ve Öneriler}

Sosyal medya platformlarının kullanımının yaygınlaşması neticesinde ebeveynlerin ve öğretmenlerin çocukların fotoğraflarını, görüntülerini izinli veya izinsiz bu platformlar üzerinden paylaşmaları bazı sakıncaları da beraberinde getirmektedir. Ebeveynlerin ve öğretmenlerin, paylaşımları yaparken dikkatli ve özenli davranmaları, çocukların sanal ortamlarda yapılan bu paylaşımlarla ilgili ilerleyen zamanlarda neler hissedebileceklerini düşünmeleri gerekmektedir. Sosyal medya araçları üzerinden, çocukların kişilik hakları çeşitli şekillerde ihlal edilmektedir. İzinsiz paylaşım, paylaşımlar üzerinde yapılan rencide edici yorumlar, paylaşımlar üzerinde çeşitli değişikliklerin yapılması, çocukların psikolojik olarak olumsuz etkilenmelerine neden olabilmektedir. Yetişkin bireylere göre daha korunmasız olan çocuğun kişiliğine, ebeveynlerin ve öğretmenlerin saygı duyması gerekmektedir.

Öğretmenler tarafından sınıf ortamında öğrencilerinin özel anlarının izinsiz bir şekilde kayda alınıp, binlerce kişinin ulaşabileceği bir şekilde sosyal medya platformlarında paylaşılması, kişisel hak ve hürriyete aykırıdır. Bu tür kontrolsüz bilinçsiz davranışlar öğretmenler açısından istenmeyen bazı hukuki sonuçların ortaya çıkmasına neden olabilecektir. Çocuklara, ebeveynlerinin, öğretmen ve okul yöneticilerinin tasarrufu altındaki bir obje olarak değil, yetişkinler gibi kişisel hakları olan bireyler olarak bakılmalıdır. Ebeveynler ve eğitimciler çocuklara karşı olan yasal, etik sorumluluklarının farkında olmalıdır. 
Çocukla temas eden ebeveyn, öğretmen ve okul yöneticileri bilişim teknolojilerini kullanırken, çocuk hakları ihlalleri konusunda bilinçlendirilmelidir. Sosyal medya platformlarının veya düzenleyicilerin alacağı tedbirler, ebeveyn ve öğretmenlerin gösterecekleri özenden daha etkili olmayacaktır. Okullar, çocukların haklarının açıklandığı, haklarının farkında olmalarını ve çocuk haklarının yaygınlaştırılmasından sorumlu kurumlar olarak öncelikli olarak kendilerini görmelidir. Çocukların kişisel haklarının korunup, kollanmasıyla ilgili farkındalığın kazandırılmasında okul yöneticileri ve öğretmenlere önemli görevler düşmektedir.

Çocukların kişilik haklarını ihlal eden paylaşımların sosyal medya platformlarından kaldırılması veya bu paylaşımların engellenmesi konusu da hukuki anlamda önem arz etmektedir. Bireyler, doğrudan hizmet sağlayıcısı durumunda olan platforma ulaşarak söz konusu içerik nedeniyle bir kişilik hakkı ihlali oluştuğunu bildirilebilmekte ve içeriğin kaldırılması yönünde talepte bulunabilmektedirler. Fakat ihlal ebeveyn tarafından gerçekleştirilmişse ortaya problemli bir durum çıkabilmektedir. Çünkü farkındalığı yetişkinlere göre daha düşük olan çocuk, hangi mekanizmaları kullanıp şikâyette bulunacağını çoğu zaman bilememektedir. Çocukların birinci dereceden kendilerinden sorumlu olan ebeveynlerini şikâyet etmeleri de düşük bir olasılık olarak görülmektedir. Bazı sosyal medya platformları şikâyette bulunulan içerikleri kaldırabilmeleri için mahkeme kararı istemekte, hatta bazı durumlarda mahkeme kararlarını bile uygulamamaktadırlar. Mahkemeler sosyal medya araçları aracılığıyla gerçekleşen ihlallerin sona erdirilmesi için erişimin tamamen engellenmesi gibi kararlar verebilmektedirler (Bulut, 2018).

Sosyal medya araçlarının; çocuk hakları ihlallerinin önlenmesinde rol alacak şekilde, çocuk dostu bir anlayışla yeniden yapılandırılmasına ihtiyaç duyulmaktadır. Son dönemlerin popüler sosyal medya uygulamaları Youtube ve Instagram aracılığıyla çocuk odaklı paylaşım yapan kullanıcılarının sayısında ciddi artışlar olduğu gözlemlenmektedir. 2019 yılının ilk aylarında Youtube çocuk odaklı paylaşımlar için yorum bölümünü kapatacağını deklare etmiştir. Önemli bazı şirketler tarafından bu uygulama üzerinden çocuklara yönelik yayınlanan bazı reklamlarda uygunsuz yorumlar yapıldığı belirlenmiştir. Bununla ilgili şirketlerin reklamlarını yayından kaldırma kararı almaları yerinde olmuştur. Çocukların sosyal medya aracılığıyla istismar edilmesinin önüne geçilmesi açısından benzer önlemlerin diğer sosyal medya platformları tarafından da hayata geçirilmesi beklenmektedir.

Çocukların dijital ortamlarda zorbalığa uğrayıp, istismar edilmemesi adına çocuk hakları eğitimi önleyici bir rol oynayabilir. Bunun için gerek okul, gerekse aileler için ilgili diğer kurumlarında müdahil olacakları çocuk hakları eğitimleri planlanmalıdır. Türkiye'de çocuklar sosyal medya araçları üzerinden kişilik haklarını, özel yaşamlarını, onurlarını kırıcı, hak ihlallerine maruz kalabilmektedir. Çocuk haklarıyla ilgili mevzuat çalışmaları yapılırken; hukuk, eğitim, psikoloji, sosyoloji, bilişim teknolojileri gibi alanlardaki uzmanlar, çaış̧maları yürüten ilgili organlara yardımcı olmalıdır. 
Hüseyin SERIN

Çocukların kişilik haklarını, özel yaşamlarını sosyal medya araçları üzerinden ihlal eden ebeveyn ve öğretmenlere yönelik uygulanacak yaptırımları içeren mevcut düzenlemeler yetersiz kalmaktadır. Mevzuatın yetersizliği, caydırıcılık açısından önemli bir sorun teşkil etmektedir. Sosyal medya üzerinden kişilik hakları ihlal edilen, istismar edilen, zorbalığa ve ihmale uğrayan çocukları korumak amacıyla caydırıcı mekanizmalar oluşturulup, ayrıca çocukların rahat erişim sağlayabilecekleri "Çocuğa Yardım ve Destek Hattı" oluşturulmalıdır.

Milli Eğitim Bakanlığı ve Aile, Çalışma ve Sosyal Hizmetler Bakanlığı tarafından sosyal medya araçları üzerinden istismara uğrayan çocuklara yönelik müdahale programları geliştirilmelidir.

Türkiye'de bilişim ve iletişim sektörünü düzenleyen ve denetleyen üst kurul olan Bilgi Teknolojileri ve Illetişim Kurumu (BTK) tarafından sosyal medya aracılığıyla gerçekleşen, çocukların kişilik haklarının ihlal eden durumlara ilişkin gerekli tedbirler alınmalıdır.

\section{Kaynaklar}

Akdi, M. (2016). Ana-Babanın Çocuğun Fotoğraf ve Görüntülerinin Sosyal Medyada Yayınlamasından Doğan Sorumluluğu. Marmara Üniversitesi Hukuk Fakültesi Hukuk Araştırmaları Dergisi, 22 (3), 123-144.

Akgül, A. (2015). Kişisel Verilerin Korunmasında Yeni Bir Hak: "Unutulma Hakkı" ve AB Adalet Divanı'nın “Google Kararı”. Türkiye Barolar Birliği Dergisi, 116, 11-38.

Akyüz, E. (2000). Çocuğun Haklarının Ve Güvenliğinin Korunması (Ulusal Ve Uluslararası Hukukta). Millî Eğitim Bakanlığı Yayını, Ankara.

Akyüz, E. (2016). Çocuk Hukuku Çocukların Hakları ve Korunması. Pegem Akademi, 5.Baskı, Ankara.

Alikaşifoğlu, M. (2012). Internet Kullanımı ve Çocuk ve Ergen Sağlığı Türk Pediatri Kurumu TBMM Sunusu, https://www.tbmm.gov.tr/arastirma_komisyonlari/bilisim_internet/docs/Turk_Pedi atri_Kurumu_.internet\%20Kullanimi\%20ve\%20cocuk-Ergen-sagligi.pdf adresinden 14.10.2018 tarihinde erişilmiştir. 
Artuç, M. ve Gedikli, C. (2007). Yeni Yargıtay Kararları Işığında TCK-CMK - CGiK Çocuk Koruma Kanunu ve 5560 Sayılı Kanunla Getirilen Yenilikler (Yeni Ceza Adalet Sistemi). Kartal Yayınevi, 2.Baskı, Ankara.

Atalay, G. E. (2019). Sosyal Medya ve Çocuk: "Babishko Family Fun TV" İsimli Youtube Kanalının Eleştirel Bir Analizi. Erciyes Iletişim Dergisi Uluslararası Dijital Çağda Iletişim Sempozyumu Özel Sayısı, (1), 179-202.

Balo, Y.S.(2005). Uluslararası IIlkeler Işığında Çocuk Koruma Kanunu ve Uygulaması. Seçkin Yayınevi, Ankara.

Binark, M. ve Bayraktutan, G. (2013). Ayın Karanlık Yüzü: Yeni Medya ve Etik. Kalkedon Yayınları, İstanbul.

Bostancı, M. (2010). Sosyal medyanın gelişimi ve iletişim fakültesi öğrencilerinin sosyal medya alışkanlıkları. Yayınlanmamış Yüksek Lisans Tezi, Erciyes Üniversitesi Sosyal Bilimler Enstitüsü, Kayseri.

Boyd, D. M. \& Ellison, N. B. (2008), Social Network Sites: Definition, History, and Scholarship. Journal of Computer-Mediated Communication, 13, 210-230.

Bulut, A. (2018). Sosyal medyada hak ve özgürlüklerin kullanımı ve sınırlanması "iletişim hukuku açısından bir inceleme". Yayınlanmamış Yüksek Lisans Tezi, Marmara Üniversitesi Sosyal Bilimler Enstitüsü, İstanbul.

Cemaloğlu, N. ve Bıçak, D.K. (2015). Sosyal Ağlarda Öğretmen Öğrenci Arkadaşlığına Yönelik Öğrenci Görüşleri. Türk Eğitim Bilimleri Dergisi, 13(2), 51-76.

Çobaner, A.A. (2005). Çocuk Hakları Bağlamında Suriyeli Mülteci Çocukların Haberlerde Temsili. Marmara Iletişim Dergisi, 24, 27-54.

Çocuk Koruma Kanunu, (2005). http://www.mevzuat.gov.tr/MevzuatMetin/1.5.5395.pdf adresinden 15.11.2018 tarihinde erişilmiştir.

Dural, M. ve Öğüz, T.F. (2016). Türk Özel Hukuku, Cilt III, Aile Hukuku. Seçkin Yayıncılık, 11. Baskı, İstanbul.

Eldeniz, L. (2010). Ikinci Medya Çağında internet. Alfa Yayıncılık, İstanbul. 
Hüseyin SERIN

Gömleksiz, M., Kilimci, S., Vural, R., Demir, Ö., Koçoğlu-Meek, Ç. ve Erdal, E . (2008). Okul Bahçeleri Mercek Altında: Şiddet ve Çocuk Hakları Üzerine Nitel Bir Çalışma. IIköğretim Online, 7 (2), 273-287.

Gönen, D. (2011). Tüzel Kişilerde Kişilik Hakkı ve Korunması. On iki Levha Yayıncılık, İstanbul.

Gözler, K. (2001). Uluslararası Andlaşmaları Akdetme ve Onaylama Yetkisi: Bir Karşılaştırmalı Anayasa Hukuku İncelemesi. Ankara Üniversitesi Siyasal Bilgiler Fakültesi Dergisi, 56 (2), 71-101.

Helvacı, S. (2001). Kişilik Hakkını Koruyucu Davalar. Beta Yayınları, İstanbul.

Internet Ortamında Yapılan Yayınların Düzenlenmesi ve Bu Yayınlar Yoluyla İşlenen Suçlarla Mücadele Edilmesi Hakkında Kanun (2007). http://www.mevzuat.gov.tr/MevzuatMetin/1.5.5651.pdf adresinden 14.11.2018 tarihinde erişilmiştir.

Karakaş, B. ve Çevik, Ö.C. (2016). Çocuk Refahı: Çocuk Hakları Perspektifinden Bir Değerlendirme. Gazi Üniversitesi iktisadi ve Idari Bilimler Fakültesi Dergisi, 18 (3), 887906.

Kepenekçi, Y. (2008). Eğitimciler İçin Insan Hakları ve Vatandaşlık. Anı Yayıncılık, Ankara.

Kızılarslan, A. (2012). Sosyal medyanın toplum üzerindeki etkilerine eleştirel bir yaklaşım. Yayınlanmamış Yüksek Lisans Tezi, Marmara Üniversitesi Sosyal Bilimler Enstitüsü, İstanbul.

Küçükleri Muzır Neşriyattan Koruma Kanunu, (1927). http://www.mevzuat.gov.tr/MevzuatMetin/5.3.1117.pdf adresinden 17.11.2018 tarihinde erişilmiştir.

Mangold, W. \& G. Faulds, D. J. (2009). Social Media: The New Hybrid Element Of the Promotion Mix. Business Horizons, 52, 357-365.

Mavnacıoğlu, K. (2009). İnternette Kullanıcıların Oluşturduğu ve Dağıttığı İçeriklerin Etik Açıdan İncelenmesi: Sosyal Medya Örnekleri. Fırat Üniversitesi Iletişim Fakültesi Medya ve Etik Sempozyumu, 63-72. 
MEB, (2017). Okullarda Sosyal Medyanın Kullanılması. 2017/12 numaralı genelge, http://mevzuat.meb.gov.tr/dosyalar/1833.pdf adresinden 05.03.2019 tarihinde erişilmiştir.

Milli Eğitim Temel Kanunu, (1973). http://www.mevzuat.gov.tr/MevzuatMetin/1.5.1739.pdf adresinden 21.11.2018 tarihinde erişilmiştir.

Nasıroğlu, S. (2014). Çocuk İstismarında Rehabilitasyon ve Tedavi Merkezleri. Psikiyatride Güncel Yaklaşımlar Dergisi, 6, 67-78.

Özdemir, H. (2009). Elektronik Haberleşme Alanında Kişisel Verilerin Özel Hukuk Hükümlerine Göre Korunması. Seçkin Yayınları, Ankara.

Özel, S. (2004). Uluslararası Alanda Medya ve Internette Kişilik Hakkının Korunması. Seçkin Yayıncılık, 2. Baskı, Ankara.

Özmen, R. (2018). TC. Anayasası. Seçkin Yayıncılık, 40. Baskı. Ankara.

Pelendecioğlu, B. ve Bulut, S. (2009). Çocuğa Yönelik Aile İçi Fiziksel İstismar. Abant İzzet Baysal Üniversitesi Dergisi, 9(1), 50-62.

Serozan, R. (1977). Kişilik Hakkının Korunmasıyla ilgili Bazı Düşünceler. MHAD,11 (14) , 93-112.

Serozan, R. (2017). Çocuk Hukuku. Vedat Kitapçılık, 2.Baskı , İstanbul.

Sırabaşı, V. (2007). Internet ve Radyo-Televizyon Aracılığıla Kişilik Haklarına Tecavüz. Adalet Yayınevi, 2. Baskı, Ankara.

Taş, A. (2017). Hacettepe üniversitesi öğrencilerinin çocuk ihmal ve istismarı hakkındaki bilgi düzeylerinin incelenmesi. Yayınlanmamış Yüksek Lisans Tezi, Hacettepe Üniversitesi Sosyal Bilimler Enstitüsü, Ankara.

TBMM, (2001). Çocuk Haklarının Kullanılmasına Iliş̧kin Avrupa Sözleşmesinin Onaylanmasının Uygun Bulunduğuna Dair Kanun.

https://www.tbmm.gov.tr/tutanaklar/KANUNLAR_KARARLAR/kanuntbmmc085/kan untbmmc085/kanuntbmmc08504620.pdf adresinden 14.11.2018 tarihinde erişilmiştir. 
Hüseyin SERIN

Türk Borçlar Kanunu (2011). http://www.mevzuat.gov.tr/MevzuatMetin/1.5.6098.pdf adresinden 05.03.2019 tarihinde erişilmiştir.

\section{Türk Ceza Kanunu (2004).}

http://www.mevzuat.gov.tr/Metin1.Aspx?MevzuatKod=1.5.5237\&Mevzuatlliski=0\& sourceXmlSearch\&Tur=1\&Tertip=5\&No=5237 adresinden 18.11.2018 tarihinde erişilmiştir.

\section{Türk Medeni Kanunu (2001).}

http://www.mevzuat.gov.tr/Metin1.Aspx?MevzuatKod=1.5.4721\&Mevzuatlliski=0\& sourceXmlSearch=medeni\&Tur=1\&Tertip $=5 \&$ No=4721 adresinden 30.11.2018 tarihinde erişilmiştir.

Uğurlu, Z. ve Aksoy i, G. (2014). Çocuk Hakları ve Hukuki Bağlamda Çocuğun İhmal ve İstismardan Korunması. International Journal of Social and Educational Sciences, Uluslararası Sosyal ve Eğitim Bilimleri Dergisi, 1(1), 36-58.

Unicef ( 2018). More than 175,000 children go online for the first time every day, tapping into great opportunities, but facing grave risks, https://www.unicef.org/eca/pressreleases/more-175000-children-go-online-first-time-every-day-tapping-greatopportunities adresinden 04.03.2019 tarihinde erişilmiştir.

Usta, S. (2012). Çocuk Hakları ve Velayet. Oniki Levha Yayıncılık, İstanbul.

Zengin, M., Zengin, G., ve Altunbaş, H. (2015). Sosyal Medya ve Değişen Mahremiyet "Facebook Mahremiyeti". Gümüşhane Üniversitesi Iletişim Fakültesi Elektronik Dergisi, 3(2), 112-136.

Zeytin, Z. ve Ergün, Ö. (2018). Türk Medeni Hukuku. Seçkin Yayıncılık, Ankara.

Yengin, D. (2012). Yeni Medya ve Dokunmatik Toplum. Derin Yayınları, İstanbul

WHO (2006). Preventing Child Maltreatment: A Guide to Taking Action and Generating Evidence. Geneva, World Health Organisation.

https://www.bbc.com/turkce/haberler-dunya-42604622 adresinden 11.11 .2018 tarihinde erişilmiştir. 
https://www.bbc.com/turkce/haberler-37846302 adresinden 25.11.2018 tarihinde erişilmiş̧ir.

https://www.dw.com/tr/öğretmenlere-facebook-yasağı/a-16968462 adresinden 16.11.2018 tarihinde erişilmiştir.

https://www.ntv.com.tr/turkiye/mahkeme-cocuklarini-reklam-malzemesi-yapan-bloggerannenin-iki-cocugunubabaya-ve,qS8Pj79Zc0SNNhjagnJu8A adresinden 06.03.2019 tarihinde erişilmiştir.

https://www.statista.com/statistics/268136/top-15-countries-based-on-number-offacebook-users/adresinden 09.11.2018 tarihinde erişilmiştir.

https://www.statista.com/statistics/578364/countries-with-most-instagramusers/adresinden 08.11.2018 tarihinde erişilmiştir.

http://tkb.meb.gov.tr/www/ses-goruntu-ve-video-paylasimi/icerik/69 adresinden 07.03.2019 tarihinde erişilmiştir.

https://www.usatoday.com/story/news/nation-now/2016/09/16/18-year-old-suesparents-posting-baby-pictures-facebook/90479402/ adresinden 03.03.2019 tarihinde erişilmiştir.

https://wearesocial.com/uk/blog/2018/10/the-state-of-the-internet-in-q4-2018 adresinden 08.11.2018 tarihinde erişilmiştir.

https://wearesocial.com/global-digital-report-2019_adresinden 08.02.2019 tarihinde erişilmiştir.

https://webional.com/mutlaka-bilinmesi-gereken-28-instagram-istatistigi/adresinden 01.12.2018 tarihinde erişilmiştir. 